УДК 159.9

\title{
СОВРЕМЕННЫЕ МОДЕЛИ МЕЖПОКОЛЕННЫХ ОТНОШЕНИЙ В ПОЛНЫХ И НЕПОЛНЫХ СЕМЬЯХ
}

\author{
Красавина Надежда Сергеевна \\ педагог-психолог \\ ГБОУ СОШ № 436
}

\begin{abstract}
Аннотация: В современном мире существенно возрос интерес к семье и к ее роли в процессе формирования гармоничной личности ребенка. В данной статье отражено описание современных моделей межпоколенных отношений в полных и неполных семьях. Раскрыты основные виды взаимоотношений между членами семьи в полных и неполных семьях, а также перечислены риски воспитания детей в неполных семьях.
\end{abstract}

Ключевые слова: полные семьи, неполные семьи, межпоколенные отношения, семья, модели отношений.

\section{MODERN MODELS OF INTERGENERATIONAL RELATIONSHIPS IN COMPLETE AND INCOMPLETE FAMILIES}

\section{Krasavina Nadezhda Sergeevna}

\begin{abstract}
In the modern world, interest in the family and its role in the process of forming a harmonious personality of a child has significantly increased. This article describes the description of modern models of intergenerational relationships in complete and single-parent families. The main types of relationships between family members in complete and incomplete families are revealed, and the risks of raising children in single-parent families are also listed.
\end{abstract}

Key words: complete families, single-parent families, intergenerational relationships, family, relationship models

В современном мире существенно возрос интерес к семье и к ее роли в процессе формирования гармоничной личности ребенка. Стабильность и устойчивость института семьи гарантирует четкие реакции на социальные и экономические процессы, происходящие в обществе, с помощью изменений во внутрисемейных отношениях. Известным фактом является то, что нарушения в 
семейном воспитании и дисгармоничность в общении между значимыми для ребенка взрослыми существенно влияют возникновение проблем в психическом развитии детей.

Проблему семейного воспитания рассматривали такие ученые как Ю.П. Азаров, Ф.Я. Байков, Э.В. Васильева, В.Н. Гуров, Е.В. Каган и другие. На протяжении долгих лет понятие «семья» определяется как «основанная на браке или кровном родстве малая группа, члены которой связаны общностью быта, взаимной помощью и моральной ответственностью». Значение семьи как института воспитания заключается в том, что именно в ней ребенок находится в течение большей части своей жизни, а, следовательно, ощущает в ней наиболее значимое воздействие на личность, с которым не может сравниться ни один из институтов воспитания.

Неоценимость и многогранность влияния семьи на личность обусловливают большое количество подходов к изучению семьи. Условия жизни конкретной семьи зависит от развития общества, в котором она находится. Эти условия определяют функции семьи, а также обобщены в моральных нормах. Это играет определенную роль в распределении позиций между членами семьи и отражается в особенностях взаимоотношений между людьми.

Общеизвестно, что выделяют полные и неполные семьи. Полная семья это «семья, состоящая из супружеской пары с детьми любого возраста или без детей» [1, с. 264]. Неполная семья - «категория семей, в которых одинокий родитель проживает с ребенком (детьми) несовершеннолетнего возраста и несет за него (них) основную ответственность» [2, с. 158].

Рассмотрим семью как основу для развития ребенка.

Пока ребенок мал, семья способна оказать наибольшее воздействие на то, каким он вырастет и кем станет в будущем, способна предопределить его место в обществе. Тип семьи, в которой рождается ребенок, может как позитивно, так и негативно повлиять на его ожидания, умение строить взаимоотношения с другими людьми, а также на приобретаемый им жизненный опыт в целом, включая психоэмоциональное, интеллектуальное, физическое и социальное развитие.

Одной из главных функций семьи является удовлетворение потребностей человека. Гармоничное развитие личности ребенка возможно при сохранении и укреплении его здоровья, включающего как физическое, так и психологическое и социальное благополучие. Для этого необходимо учитывать: 
- Ребенок сам осознает свою роль в семье, определяет в ней приемлемое для него поведение, выясняет свое отношение к близким людям и к себе самому.

- Ребенок из-за отсутствия большого жизненного опыта и недостаточно сформированного мышления иначе воспринимает происходящее вокруг.

- На ребенка влияют не только продуманные заранее и целенаправленные воспитательные воздействия, но «случайные» поступки родителей в равной степени.

На процесс обучения, воспитания и развития ребенка влияют множество факторов: стиль родительского воспитания, количество детей в семье, их возраст, пол и характер взаимоотношений между братьями и сестрами, действующая система поощрений и наказаний, условия жизни семьи, количество проживающих членов семьи, их занятость и другое.

Джуди Данн выделяет пять основных направлений для различия отношений между детьми в одной семье: соперничество, привязанность, безопасность, близость, общие фантазии [3, с. 612].

Одна из причин по которым ребенок отличается от своих братьев и сестер, состоит в том, что ему необходимо выделить свою неповторимую идентичность. Так, если старший ребенок послушен, сосредоточен и внимателен, младший может стать активным и неусидчивым. Еще одна из причин связана с неповторимостью личного опыта ребенка. Каждый ребенок, даже несмотря на то, что он участвует в одних и тех же событиях, происходящих в семье, имеет собственные личные переживания, которые неизвестны и сокрыты от других членов семьи.

Младшие дети опираются на модель поведения старших. Доказано, что в семьях, в которых есть дети одинакового пола, младшие проявляют более типичное для своего пола поведение, чем в тех семьях, в которых у детей пол не совпадает с полом старших в семье. Кроме того, чем меньше разница в возрасте у братьев или сестер, тем интенсивнее их отношения.

Немаловажна роль бабушек и дедушек в семейном воспитании, поскольку их функции значительно отличаются от родительских из-за иной привязанности к внукам. Они чаще выражают одобрение, поощряют действия детей, сочувствуют им и поддерживают, при этом, реже наказывая. У дедушек и бабушек часто есть свободное время, чтобы рассказать ребенку истории из своего детства, что формирует у ребенка чувства семейной идентичности. 
Дети, растущие в неполной семье, где главой является мать, подвержены социальному риску. Женщины, воспитывающие детей в таких семьях, нередко психологически менее устойчивы вследствие постоянного ежедневного напряжения и непрекращающейся борьбы за экономическое благополучие семьи. Многим это совместно с накопленной тревогой мешает быть внимательными матерями. Дети, растущие в таких семьях, повторяют жизненный сценарий родителей и оказываются родителями-одиночками, передавая проблемы следующему поколению.

Неполная семья сегодня нередко испытывает трудность в выполнении своей главной функции и не может способствовать гармоничному развитию личности, развивающейся в ней и не является психологической защитой для ребенка.

В.С. Мухина отмечает, что воспитание детей в неполной семье имеет ряд особенностей. Из-за отсутствия одного из родителей оставшийся берет на себя решение всех материальных и бытовых проблем семьи, одновременно

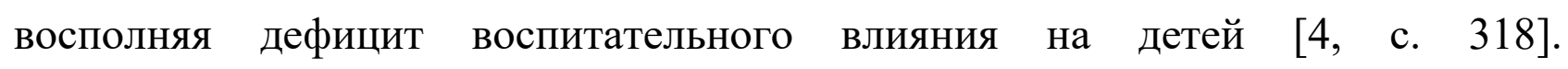
Психологический климат неполной семьи часто нарушен и неустойчив из-за присутствия в жизни родителя и детей переживаний, возникшими вследствие отсутствия одного из родителей.

Наиболее распространенными стилями воспитания в неполных семьях являются гипопротекция, когда родитель крайне мало интересуются делами, успехами, переживаниями ребенка; потворствующая гиперпротекция, несущая в себе повышенное внимание к ребенку в сочетании с тесным эмоциональным контактом, полным приятием всех поведенческих проявлений; или эмоциональное отвержение. Ни один из перечисленных стилей воспитания не оказывает благотворное влияние на развитие личности ребенка.

В заключение следует сказать, что установки, ценности и ожидания детей связаны с тем, какое воспитание они получили. Полные и неполные семьи вырабатывают свою собственную идентичность и модели воспитания детей в результате взаимодействия исторического контекста, в котором они находятся. 


\section{Список литературы}

1. Безрукова В.С. Основы духовной культуры [Текст] / В.С. Безрукова. Екатеринбург: Энциклопедический словарь педагога, 2000. - 937 с.

2. Карабанова О.А. Психология семейных отношений: Учебное пособие. - Самара: СИОКПП, 2001. - 122 с.

3. Шнейдер Л.Б. «Основы семейной психологии» - М.: Изд-во Московского психолого-социального института; Воронеж: НПО МОДЭК, 2005. $-928 \mathrm{c}$.

4. Мухина В.С. Возрастная психология: Феноменология развития, детство, отрочество. М.: Академия, 2003. - 456 с.

(C) Красавина Н.С, 2021 